\title{
Factors Effecting Towards Personal Bankruptcy among Residents: Case Study in Klang Valley, Malaysia
}

\author{
Mahiswaran Selvanathan, PhD (Corresponding author) \\ SEGi University, Malaysia \\ Email: mahiswaran@gmail.com \\ Uma Devi Krisnan \\ SEGi University, Malaysia \\ Wong Chui Wen \\ SEGi University, Malaysia
}

Received: July 22, 2016 Accepted: September 08, 2016 Published: October 03, 2016

doi:10.5296/ijhrs.v6i3.10092 URL: http://dx.doi.org/10.5296/ijhrs.v6i3.10092

\begin{abstract}
In Malaysia, there is a notable increase in the number of bankruptcy cases. The personal bankruptcy trend has become one of the major concern to the government. The purpose of this research is to study the factors lead to personal bankruptcy. This research tested the few factors effect on personal bankruptcy based on Klang Valley residents. The research used a quantitative approach and data was gathered from survey questionnaire. The questionnaire measurement quantifies the respondent's response with the help of five point Likert scale. Respondents were designated to respond on the questionnaire by simple random sampling techniques. Data collected was analyzed using Pearson correlation coefficient and multiple regression analysis. The data has been presented in the form of tables. Relationships that were assessed are credit card debts, money management, financial literacy and non-performing loan effects towards personal bankruptcy. The finding shows that there are positive relationship between money management, financial literacy and non-performing loan.
\end{abstract}

Keywords: Personal bankruptcy, Credit card debts, Money management, Financial literacy, Non- performing loan 


\section{Introduction}

Bankruptcy is a legal process where the High Court announced a bankrupt pursuant to an Adjudication Order against an individual, also known as a debtor, who unable to settle his debts (Shaliza, Hilwa, \& Norasyikin, 2013). A bankruptcy act can only be implemented after a default period of six months. Furthermore, the debtor must inhabit in Malaysia at least one year for bankruptcy petition (Malaysia Department of Insolvency, 2013).

When an individual has declared bankruptcy, all the assets owned will confer on the Director General of Insolvency (DGI) to sell in order to repay the outstanding debts. Under Section 8(2) of the Bankruptcy Act, secured creditors may deal with bankrupt's property within six months from the date of Receiving Order. However, unsecured creditors have no power to deal those property unless there is a leave of the court for any legal actions or able to file their Proof of Debt (Law of Malaysia, 2006).

Furthermore, the bankrupts have to comply with some rules and regulations until their debts paid off. According to Bankruptcy Act 1967, a Malaysian who declared bankruptcy has to give up all the assets and belongings. Besides, the bankrupts are not permitted to open a bank account or travel abroad without the approval of the Director General of Insolvency (DGI). The bankrupts are not allowed to start any business nor be a part of any company's management before discharged from bankruptcy. Also, the bankrupt has to take out a certain percentage of the monthly income for debts repayment.

According to Malaysia Department of Insolvency (MDI), the bankruptcy petition can be applied either by the debtors or creditors when the liquidated outstanding debt amount involved is not less than RM 30,000. In Malaysia, there is a notable increase in a number of bankruptcy cases in recent years (Yuen, 2014). People nowadays accumulate debt faster than the growth in income which lead to repayment difficulties and thus declared bankrupts (Chow, 2015). Therefore, the government of Malaysia should pay more efforts in order to combat personal bankruptcy. Personal bankruptcy trend has become one of the major concern to the Malaysia government. According to Malaysia Department of Insolvency (2012), there are total of 86,944 individuals had been declared bankrupt from the year 2008 to 2012 .

In order to control bankruptcies, Bank Negara Malaysia (BNM) has set up two agencies in April 2006, which known as the Department of Insolvency (MDI) and Agensi Kaunselingdan Pengurusan Kredit (AKPK). The mission of Malaysia Department of Insolvency (MDI) is to facilitate and control bankruptcy problems while Agensi Kaunselingdan Pengurusan Kredit (AKPK) is playing a role of providing financial information as well as debt reschedule plan for individuals who are facing financial problems (Cheng, Wei, Rajagopalan, \& Hamid, 2015). However, the increasing number of bankruptcies cases from 2008 to 2012 showing that the agencies are not effective in curbing the problem.

\section{Literature Review}

\subsection{Personal Bankruptcy}

Personal bankruptcy is a common issue that happens in every country, whereas in Malaysia, 
the personal bankruptcy cases increased from 13,855 cases in 2008 to 19,575 in 2012 (Malaysia Department of Insolvency, 2013). Researchers identified that the increase in personal bankruptcy is due to the rise of non-performing loan, incapability in money management (Cheng, et. al., 2015; Hancock, Jorgensen, \& Savla, 2013) and lack of financial knowledge (Roberts \& Jones, 2001;Huhmann \& McQuitty, 2009).

Furthermore, a panel study of income dynamics indicates the most common cause of personal bankruptcy is high personal debts (Kaviyarasu, 2012). Besides, two-thirds of National Foundation of Credit Counselling respondents commented that excessive spending is the cause of financial difficulty which leads to bankruptcy (Kaviyarasu, 2012).

Researchers debated that the medical conditions lead to credit card debts (Domowitz\& Sartain, 1999).In addition, researchers acknowledge the credit card holders are more likely to become bankrupts as the credit cards debts increases (Kaviyarasu, 2012; Gross \& Souleles, 2002). Therefore, the increase in bankruptcy is due to the credit card debts as well as the reducing punishment to bankrupts (Livshits, MacGee, \&Tertilt, 2007).

\subsection{The Effects of Credit Card Debts towards Personal Bankruptcy}

Credit cards were first issued in Malaysia in the mid-1970s (Zafar, Ishak, Sadiq, Ibrahim, \& Alias, 2010). At the beginning, credit cards only can be applied by professionals and businessmen. However, individuals nowadays can easily obtain credit cards regardless of the income and occupation (Noordin, Zakaria, Sawal, Ngah, \&Hussin, 2012). As the result, the number of credit card holders had reached about three million on last century (Zafar,et. al., 2010). The increased usage of credit card affect the credit card holders in spending behaviour.

Credit card holders tend to be involved in higher spending behaviour, heavier debts as well as impulsive purchasing (Teo, Sabri, Rahim, Othman, \&Arif, 2013). Hence, easy access to a credit card is one of the reasons of overspending (Schor, 1998). Similarly, a researcher revealed that credit card holders tend to purchase more than those without credit cards (Feinberg, 1986). This showed that credit cards directly related to the explosion in consumer debt as well as personal bankruptcy.

In March 2009, the outstanding payment from credit card holders in Malaysia reaches up to RM15.719 billion(Zafar,et. al.,2010).There is total of 3,548 individuals declared bankruptcy from the year 2005 to 2009 due to credit card debts (Bank Negara Malaysia, 2009). This sufficiently shows that the seriousness of the bankruptcy due to credit card debts. Therefore, the first hypothesis was generated as per below:

$H_{1}$ : There is a positive relationship between credit card debts and personal bankruptcy.

\subsection{The Effects of Poor Money Management towards Personal Bankruptcy}

Money management is defined as the ability to save and manage money (Teo,et. al., 2013). Credit Counseling Society of British Columbia indicated that individuals with money 
management skills able to spend money wisely and poor money management will put individuals in bankruptcy to (Teo, et. al., 2013). Consequently, the thoughtless spending and the pursuing of luxury life are one of the factors that trigger personal bankruptcy (Shaliza,et. al., 2013).

Moreover, the researcher argued that psychographic factors are the main causes that influence an individual's financial management (Remund, 2010). This is identified when individuals with low self-control unable to hold the savings from impulsive purchases and individuals with low self-efficacy facing difficulties in managing financial for debts repayment(Chenget. al., 2015).

Similarly, researchers discovered that individuals with poor money management tend to save less and involved in high borrowing behaviour (Othman, Rahim, \&Sabri, 2015). This may to the extent being trapped in financial obligation as well as facing bankruptcy. Reversely, individuals with good money management skills will have the ability to control the spending behaviour (Delafrooz\& Pain, 2011; Hayhoe,Leach, Turner, Bruin, \& Lawrence, 2000). Most of the Malaysian are lacking in term of money management skills (Ibrahim, Harun, \& Isa, 2010). Therefore, this would be one of the reasons of increasing bankruptcy in Malaysia.

$\mathrm{H}_{2}$ : There is a positive relationship between poor money management and personal bankruptcy.

\subsection{The Effects of Financial Literacy towards Personal Bankruptcy}

Financial literacy is defined as information of facts, concepts, and principles that can be utilized in financial decision making (Garman, Kim, Kratzer, Bunson,\&Joo,1999). It is a skill that allows an individual to assess the suitability of expenses as well as influence an individual on savings and budgeting (Onyango, 2014). Researchers indicated that financial literacy was the predictor for managing the money (Teo,et. al.,2013). Weak financial literacy will lead to poor money management as those people do not have a proper understanding of financial knowledge and vice versa (Rooij, Lusardi, \&Alessie, 2007). Those individuals tend to have high savings and low borrowings.

Financial literacy will directly affect individual financial capabilities to make the financial decisions (Lusardi,\&Mitchell, 2009).Consequently, individuals that lacking of financial literacy will probably have low ability to make positive decisions regarding financial problems (Othman, et. al.,2015). This is because many people unable to understand basic financial knowledge (Samy, Nagar, Huang, \&Tawfik, 2008; Lusardi, Mitchell, \&Curto, 2010). Those individuals are likely to face financial problems and unable to take an accurate decision when dealing with financial matters. Hence, individuals with low level of financial knowledge will lead to financial difficulties and resulted in bankrupts (Huhmann \& McQuitty, 2009; Othman, et. al., 2015). 


\section{Macrothink \\ International Journal of Human Resource Studies \\ ISSN 2162-3058 2016, Vol. 6, No. 3}

$H_{3}$ : There is a positive relationship between financial literacy and personal bankruptcy.

\subsection{The Effects of Non- Performing Loan towards Personal Bankruptcy}

Non-Performing Loan (NPL) is defined as the loans on which the debtors unable to make contractual payments for a predetermined period (Gorter, \&Bloem, 2001). There are increasing default payments and bankruptcy cases in Malaysia (Sabri, \&Paim, 2012). According to the data from Malaysia Department of Insolvency (2013), there is a total of 62,122 cases of bankruptcy from 2008 to 2012 due to non-performing loan.

Refer to the loan data from banks, researchers indicated that the increased in credit with the rises in non-performing loan (Delgado \&Saurina, 2004). Current studies on personal bankruptcy revealed that loan is the primary reason that caused rising in personal bankruptcy. Consequently, individuals tend to face difficulties in loan repayment due to high-interest rates (White, 2007; Godwin, 1999).Furthermore, researchers stated that higher amount of borrowings are probably having negative net-worth and thus will lead to personal bankruptcy (Brown \& Taylor 2008; Delgado \&Saurina, 2004). It clearly is seen that the inability to repay loans are the major contributor to personal bankruptcy (Malaysia Department of Insolvency, 2013). Thus, it can be concluded that the rise in the non-performing loan will lead to the increase in personal bankruptcy in Malaysia.

$H_{4}$ : There is a positive relationship between non-performing loan and personal bankruptcy.

\section{Findings}

The Pearson Correlation Coefficient employed to indicate the relationship between personal bankruptcy and independent variables. The result was presented in Table 1. 
Table 1: The Pearson Correlation Coefficient for Personal Bankruptcy

\begin{tabular}{|c|c|c|c|c|c|c|}
\hline & & $\begin{array}{l}\text { Personal } \\
\text { bankruptcy }\end{array}$ & $\begin{array}{l}\text { Credit card } \\
\text { debts }\end{array}$ & $\begin{array}{l}\text { Money } \\
\text { management }\end{array}$ & $\begin{array}{l}\text { Financial } \\
\text { literacy }\end{array}$ & $\begin{array}{l}\text { Non-performing } \\
\text { loan }\end{array}$ \\
\hline & $\begin{array}{l}\text { Pearson } \\
\text { Correlation }\end{array}$ & 1 & $.401^{* *}$ & $.626^{* *}$ & -.173 & -.034 \\
\hline bankruptcy & Sig. (2-tailed) & & .000 & .000 & .059 & .713 \\
\hline & $\mathrm{N}$ & 120 & 120 & 120 & 120 & 120 \\
\hline & $\begin{array}{l}\text { Pearson } \\
\text { Correlation }\end{array}$ & & 1 & $.514^{* *}$ & $-.252^{* *}$ & -.156 \\
\hline debts & Sig. (2-tailed) & & & .000 & .006 & .089 \\
\hline & $\mathrm{N}$ & & 120 & 120 & 120 & 120 \\
\hline & $\begin{array}{l}\text { Pearson } \\
\text { Correlation }\end{array}$ & & & 1 & -.155 & -.132 \\
\hline management & Sig. (2-tailed) & & & & .092 & .149 \\
\hline & $\mathrm{N}$ & & & 120 & 120 & 120 \\
\hline & $\begin{array}{l}\text { Pearson } \\
\text { Correlation }\end{array}$ & & & & 1 & $.743^{* *}$ \\
\hline literacy & Sig. (2-tailed) & & & & & .000 \\
\hline & $\mathrm{N}$ & & & & 120 & 120 \\
\hline Non-performing & $\begin{array}{l}\text { Pearson } \\
\text { Correlation }\end{array}$ & & & & & 1 \\
\hline & Sig. (2-tailed) & & & & & \\
\hline
\end{tabular}

**. Correlation is significant at the 0.01 level (2-tailed). 


\section{Macrothink}

International Journal of Human Resource Studies

ISSN 2162-3058

2016, Vol. 6, No. 3

Table 1 show the results of correlation between the dependent variable and independent variables which are used to examine the hypothesis in this research. Personal bankruptcy shows a moderate correlation with credit card debts and a high correlation with the money management. However, personal bankruptcy reveals a very low correlation with financial literacy and non-performing loan. Next, credit card debts show moderate correlation with personal bankruptcy as well as money management. The results of correlation analysis of credit card debts with financial literacy and non-performing loan display a very low correlation. Moreover, the money management reveals moderate correlation with personal bankruptcy and credit card debts. Also, money management shows a very low correlation with financial literacy and non-performing loan. Furthermore, non-performing loan displays a low correlation with personal bankruptcy, credit card debts, and money management. However, the correlation between non-performing loan and financial literacy is high.

Table 2: Multiple Regression Analysis for Personal Bankruptcy

\begin{tabular}{|c|c|c|c|c|}
\hline $\begin{array}{l}\text { Dependent } \\
\text { Variable }\end{array}$ & Independent Variables & $\begin{array}{l}\text { Coefficient } \\
\text { Value (B) }\end{array}$ & $\begin{array}{l}\text { Significant } \\
\text { Value (Sig.) }\end{array}$ & $\mathbf{R}^{2}$ \\
\hline & Credit Card Debts & .080 & .343 & \\
\hline Personal & Money Management & .579 & .000 & .427 \\
\hline \multirow[t]{2}{*}{ Bankruptcy } & Financial Literacy & -.233 & .033 & \\
\hline & Non-Performing Loan & .228 & .033 & \\
\hline
\end{tabular}

The R2 indicates that $42.7 \%$ of the total variance in the dependent variable (personal bankruptcy) is explained by the total independent variables (credit card debts, money management, financial literacy, and non-performing loan).The arrangement of strengths among the independent variables (credit card debts, money management, financial literacy, and non-performing loan) that contributes to the dependent variable (personal bankruptcy) are credit card debts $(\mathrm{B}=.080)$, money management $(\mathrm{B}=.579)$, non-performing loan $(\mathrm{B}=.228)$, and financial literacy $(\mathrm{B}=-.233)$. Therefore, the results of hypotheses were presented below: 


\section{Hypothesis Results}

\begin{tabular}{|l|l|l|}
\hline H1: & $\begin{array}{l}\text { There is a direct relationship between personal bankruptcy and credit card } \\
\text { debts. }\end{array}$ & Rejected \\
\hline H2: & $\begin{array}{l}\text { There is a direct relationship between personal bankruptcy and money } \\
\text { management. }\end{array}$ & Accepted \\
\hline H3: & $\begin{array}{l}\text { There is a direct relationship between personal bankruptcy and financial } \\
\text { literacy. }\end{array}$ & Accepted \\
\hline H4: & $\begin{array}{l}\text { There is a direct relationship between personal bankruptcy and } \\
\text { non-performing loan. }\end{array}$ & Accepted \\
\hline
\end{tabular}

\section{Discussion and Conclusion}

\subsection{To Find the Relationship between Personal Bankruptcy and Credit Card Debts}

Based on the result of this research, the hypotheses that illustrates there is a positive relationship between personal bankruptcy and credit card debts are rejected. In contrast to the result of this study, the previous researches indicate that there is a positive relationship between personal bankruptcy and credit card debts. According to the empirical study of Schor (1998), there is direct relationship between personal bankruptcy and credit card debts. Similar to the research conducted by Feinberg (1986), which concluded that credit card debts is one of the factors of personal bankruptcy. Also, Teo, et. al.,(2013) found that rising credit card debts will cause the increase in personal bankruptcy.

\subsection{To Find the Relationship between Personal Bankruptcy and Money Management}

The next objective of this research is to find the relationship between personal bankruptcy and money management. Based on this result of this study, the hypothesis that demonstrates a positive relationship between personal bankruptcy and money management is accepted. Similar to the result of the study, there are few previous researches reveal that there is a direct relationship between personal bankruptcy and money management. According to Shaliza, et. al.,(2013), poor money management is one of the reasons that leads to personal bankruptcy. Besides, Othman, et.al.,(2015) stated that there is a direct relationship between money management and personal bankruptcy. Moreover, Ibrahim, Harun, \& Isa, (2010) found that one of the factors of increasing bankruptcy cases in Malaysia is the lacking of money management skills.

\subsection{To Find the Relationship between Personal Bankruptcy and Financial Literacy}

Another objective of this research is to find the relationship between personal bankruptcy and financial literacy. Refer to the results of the findings, the hypothesis of this study that stated 
there is a positive relationship between personal bankruptcy and financial literacy is accepted. Similar to the results of this study, Lusardi, et. al.,(2009) supported the statement of positive relationship between personal bankruptcy and financial literacy. Refer to the research of Huhmann \& McQuitty (2009), the financial literacy is diametrically related to personal bankruptcy. Furthermore, Othman, et. al.,(2015) revealed that individuals who lacking of financial literacy are likely to face financial problems or bankruptcy.

\subsection{To Find the Relationship between Personal Bankruptcy and Non-Performing Loan}

The last research objective of this study is to find the relationship between personal bankruptcy and non-performing loan. The hypothesis of this research that indicates there is a positive relationship between personal bankruptcy and non-performing loan is accepted. There are also some previous studies that showing there is a positive relationship between personal bankruptcy and non-performing loan. According to the research of White (2007), the primary factor that caused increasing bankruptcy cases is failed to repay the loan borrowed. Besides, Brown and Taylor (2008) stated that high borrowings will lead to personal bankruptcy. Also, the study of Delgado \& Saurina (2004) indicated that non-performing loan would results in personal bankruptcy.

\section{Reference}

Adriaan, M.B., \&Russel, F. (2005). The Treatment of Nonperforming Loans. Retrieved from Statistics Department International Monetary Fund: https://www.imf.org/external/pubs/ft/bop/2005/05-29.pdf

Brown, S., \& Taylor, K. (2008). Household debt and financial assets: evidence from Germany, Great Britain and the USA. Journal of the Royal Statistical Society: Series A (Statistics in Society), 171(3), 615-643.

Cheng, E. H., Wei, K. K., Rajagopalan, U., \& Hamid, B. A. (2014). Causality of Personal Bankruptcy in Malaysia.Handbook on the Emerging Trends in Scientific Research, 363-367.

Delafrooz, N., \& Pain, L. H. (2011). Determinants of saving behavior and financial problem among employees in Malaysia. Australian Journal of Basic and Applied Sciences, 5(7), 222-228.

Delgado, J., \&Saurina, J. (2004). Credit risk and loan loss provisions. An analysis with macroeconomic variables. Directorate General Banking Regulation, Bank of Spain.

Domowitz, I., \& Sartain, R. L. (1999). Determinants of the consumer bankruptcy decision. The Journal of Finance, 54(1), 403-420.

Falahati, L., Sabri, M. F., \&Paim, L. H. (2012). Assessment a model of financial satisfaction predictors: Examining the mediate effect of financial behaviour and financial strain. World Applied Sciences Journal, 20(2), 190-197.

Feinberg,R.A. (1986). Credit Cards as Spending Facilitating Stimuli: A Conditioning 
Interpretationll. Journal of Consumer Research, 12,384-356.

Gorter, M. C., \&Bloem, M. A. M. (2001). The treatment of nonperforming loans in macroeconomic statistics (No. 1-209). International Monetary Fund.

Garman, E.T., Kim, J.,Kratzer, C.Y., Bunson, B.H.,\&Joo, S.H. (1999). Workplace Financial Education:Improved financial wellness. Association of Financial Counselling and Planning Education, 79-88.

Gross, D. B., \&Souleles, N. S. (2002). An Empirical Analysis of Personal Bankruptcy ans Delinquency. The review of Financial Studies, 15(1),319-347

Hair, J.K., Black, B. R., Babin, H. B., Anderson, P. R., \&Tatham, C.R (2006). Multivariate data analysis. 6th edition. New Jersey. Pearson Education, Inc.

Hayhoe, C. R., Leach, L. J., Turner, P. R., Bruin, M. J., \& Lawrence, F. C. (2000). Differences in spending habits and credit use of college students. Journal of Consumer Affairs, 34(1), 113-133.

Huhmann, B.A., \&McQuitty, S.(2009). A model of consumer financial numeracy. International Journal of Bank Marketing, 27 (4), 270-293.

Ibrahim, D., Harun, R., \& Isa, Z. M. (2010). A study on financial literacy of Malaysian degree students. Cross-Cultural Communication, 5(4), 51-59.

Hancock, A. M., Jorgensen,B.L.,\&Savla, J. (2013). College students and Credit Card Use: The Role of Parents, Work Experience, Financial Knowledge, and Credit Card Attitudes. Journal of Family and Economic Issues, 34(4), 369-381

Ibrahim, D., Harun, R.,\& Isa, Z. M. (2010). A study on financial literacy of Malaysian degree students. Cross-Cultural Communication, 5(4), 51-59.

Kaviyarasu, E. (2012). Usage of Credit Cards beyond Limit: A Case Study ofYoungerGenerations in Malaysia. International. Journal of Academic Research in Accounting, Finance and Management Sciences, 2(4), 330-338.

Law of Malaysia. (2006). Act 360 Bankruptcy Act 1967. Retrieved from Malaysia Department of Insolvency Web site: http://www.insolvensi.gov.my/about-us/resources/laws/231-act-360-bankruptcy-act-1967

Livshits, I., MacGee, J., \&Tertilt, M. (2007). Accounting for the rise in consumer bankruptcies (No. w13363). National Bureau of Economic Research.

Lusardi, A.,Mitchell, O. M., \&Curto, V. (2010). Financial literacy among the young. The Journal of Consumer Affairs, 44(2), 358-380.

Lusardi, A.,\&Mitchell, O.S. (2009).How ordinary consumers make complex economic decisions:Financial literacy and retirement readiness. National Bureau of Economic Research.

Malaysia Department of Insolvency. (2013). Personal Bankruptcy. Retrieved from Malaysia 
Department

of

Insolvency

Web

site:

http://www.insolvensi.gov.my/about-us/core-business/core-business/personal-bankruptcy

Noordin, N., Zakaria, Z., Sawal, M. Z. H. M., Ngah, K., \&Hussin, Z. H. (2012). Bankruptcy among young executives in Malaysia.2012 International Conference on Economics Marketing and Management, 28, 132-136.

Onyango, O. S. (2014). Effect of Financial Literacy on Management of Personal Finances among Employees of Commercial Banks in Kenya.

Othman, M. A., Rahim, H. A., Sabri, M. F. (2015). Differences in Financial Information and Financial Status among Malaysian Bankrupts. Proceedings of the Australasian Conference on Business and Social Sciences, 525- 531.

Remund, D. L. (2010). Financial literacy explicated: The case for a clearer definition in an increasingly complex economy. Journal of Consumer Affairs, 44(2), 276-295.

Roberts, J.A., \&Jones, E. (2001). Money attitudes, credit card use, and compulsive buying among American college students. Journal of Consumer Affairs, 35(21), 213-240.

Rooij, J., Lusardi, A., \&Alessie, B. (2007). Financial literacy and retirement preparedness. Pearson Prentice-hall.

Samy, M., Nagar, A. K., Huang, R.,\&Tawfik, H. (2008). Financial literacy of youth: A sensitivity analysis of the determinants. International Journal of Economic Sciences and Applied Research, 1(1), 55-70.

Saul, M. (2008). Likert Scale. $\quad$ Retrieved from http://www.simplypsychology.org/likert-scale.html

Schor, J. (1998). The overspent American: Up scaling. Downshifting and new Consumer. New York: Basic Books.

Shaliza, A.M., Hilwa, H., Norasyikin, A.F. (2013). Factors Affecting Bankruptcy: The Case Of Malaysia. International Journal of Undergraduate Studies, 2(3), 4-8.

Teo, T. J., Sabri, M. F., Rahim, H. A., Othman, M. A., \&Arif, A. M. (2013). The Influence of Financial Knowledge, Financial Practices and Self-esteem on Money Management Skills of Young Adults. Malaysian Journal of Youth Studies. 23-37.

White M. J. (2007). Bankruptcy Reform and Credit Cards. NBER Working Paper Series, Working Paper 13265, National Bureau of Economic Research.

Yuen, M.K. (2014). Bankruptcy CasesontheRisein Malaysia. Retrieved from http://www.thestar.com.my/News/Nation/2014/04/09/Bankruptcy-on-the-rise-in-Malaysia/

Zafar, U. A., Ishak, I. M.,Sadiq, S.,Ibrahim, T., \&Alias, H. (2010). Malaysian consumers'credit card usage behavior. Asia Pacific Journal of Marketing and Logistics, 22 (4), 528 - 544.

Zikmund, W. G. (2012). Business Research Methods. Boston: Cengage Learning. 


\section{Macrothink}

International Journal of Human Resource Studies

ISSN 2162-3058

\section{Copyright Disclaimer}

Copyright for this article is retained by the author(s), with first publication rights granted to the journal.

This is an open-access article distributed under the terms and conditions of the Creative Commons Attribution license (http://creativecommons.org/licenses/by/3.0/). 